\title{
PERBEDAAN SENAM OTAK DAN SENAM POCO-POCO MENINGKATKAN FUNGSI EKSEKUTIF LANSIA: STUDI EKSPERIMENTAL DI PUSAT SANTUNAN KELUARGA
}

\author{
THE DIFFERENCE OF BRAIN GYM AND POCO-POCO GYMNASTICS \\ IMPROVING EXECUTIVE FUNCTION OF ELDERLY: EXPERIMENTAL \\ STUDY IN PUSAT SANTUNAN KELUARGA \\ Yuliana Yosephine, * Rr Josephine Retno Widayanti, * Yuda Turana*
}

\section{ABSTRACT}

Introduction: The elderly have the risk of experiencing executive dysfunction due to structural and functional changes in neurons and synapses in the prefrontal cortex associated with aging. The brain gym and Poco-poco gymnastics can maintain and improve executive function so that productivity and quality of life of the elderly remain optimal.

Aim: To find out the difference between the effect of brain gym and Poco-poco gymnastics on improving the executive function of elderly population in Pusat Santunan Keluarga (PUSAKA).

Method: The study uses an experimental study with a nonequivalent control group design approach. Sixty elderly respondents were divided into the brain gym group $(n=30)$ and the Poco-poco gymnastics group $(n=30)$ in two different PUSAKAs. Each interventions are carried out three times a week for 30 minutes in four weeks. Analysis of the differences in the effect of brain gym and Poco-poco gymnastics on executive function of the elderly based on the mean difference in Oral Trail Making Test Form B (OTMT-B) using the Mann-Whitney test.

Result: There was an improvement in the mean duration of completion of OTMT-B after the intervention in the brain gym group and Poco-poco gymnastics group with a significant $p<0.05$. The difference in mean difference between OTMT-B after the intervention in the Poco-poco gymnastics group was higher than the brain gym group.

Discussion: The brain gym and Poco-poco gymnastics can improve the function of the elderly executive function. Improved executive function was more significant in the Poco-poco gymnastics group than the brain gym group.

Keyword: Brain gym, elderly, executive function, Oral Trail Making Test Form-B, Poco-poco gymnastics

\section{ABSTRAK}

Pendahuluan: Lansia berisiko mengalami gangguan fungsi eksekutif karena perubahan struktural dan fungsional pada neuron dan sinaps di korteks prefrontalis terkait penuaan. Senam otak dan senam Poco-poco dapat mempertahankan dan meningkatkan fungsi eksekutif sehingga produktivitas dan kualitas hidup lansia tetap optimal.

Tujuan: Untuk mengetahui perbedaan pengaruh senam otak dan senam Poco-poco terhadap peningkatan fungsi eksekutif populasi lansia di Pusat Santunan Keluarga (PUSAKA).

Metode: Penelitian menggunakan studi eksperimental dengan pendekatan nonequivalent control group design. Enam puluh lansia sebagai subyek terbagi dalam kelompok senam otak $(n=30)$ dan kelompok senam Poco-poco $(n=30)$ di dua PUSAKA. Masing-masing intervensi dilakukan sebanyak tiga kali seminggu selama 30 menit dalam empat minggu. Analisis perbedaan pengaruh senam otak dan senam Poco-poco terhadap fungsi eksekutif lansia berdasarkan selisih rerata Oral Trail Making Test Form B (OTMT-B) menggunakan uji Mann-Whitney.

Hasil: Terdapat perbaikan durasi penyelesaian OTMT-B setelah intervensi senam otak dan senam Poco-poco dengan nilai kemaknaan $\mathrm{p}<0,05$. Perbedaan selisih rerata durasi penyelesaian OTMT-B pada kelompok intervensi senam Poco-poco lebih tinggi dibandingkan kelompok senam otak.

Diskusi: Intervensi senam otak dan senam Poco-poco dapat meningkatkan fungsi eksekutif populasi lansia. Peningkatan fungsi eksekutif lebih signifikan pada kelompok intervensi senam Poco-poco dibandingkan kelompok intervensi senam otak.

Kata kunci: Fungsi eksekutif, lanjut usia, Oral Trail Making Test Form-B, senam otak, senam Poco-poco

*Fakultas Kedokteran dan Ilmu Kesehatan Universitas Katolik Indonesia Atma Jaya, Jakarta. Korespondensi: josephine.retno@ atmajaya.ac.id; flora_josephine@yahoo.com

\section{PENDAHULUAN}

Jumlah populasi lansia di Indonesia yang melebihi angka $7 \%$ dari total jumlah penduduk Indonesia menciptakan banyak tantangan, termasuk di bidang kesehatan, karena tubuh lansia secara biologis akan mengalami proses penuaan, mengakibatkan tingginya risiko lansia mengalami disabilitas dan menderita penyakit degeneratif. ${ }^{1-2}$ Geriatric giants sering dijumpai pada pasien geriatri bersamaan dengan penyakit dasarnya, salah satunya 
penurunan fungsi kognitif. ${ }^{3}$ Kondisi tersebut dapat mengakibatkan disabilitas, penurunan produktivitas dalam melakukan kegiatan fungsional sehari-hari, hingga kematian.

Fungsi eksekutif merupakan salah satu ranah fungsi kognitif yang penting bagi lansia sebagai "payung" proses koordinasi dan pengendalian dalam melakukan tindakan yang bertujuan. ${ }^{4}$ Jika fungsi eksekutif pada lansia terganggu, maka koordinasi dan pengendalian dalam melakukan tindakan yang bertujuan akan terganggu, serta bisa berdampak pada produktivitas dan kualitas hidup yang menurun. ${ }^{5}$ Beberapa cara dapat digunakan oleh lansia untuk menjaga dan mempertahankan fungsi kognitif, terutama fungsi eksekutifnya, seperti melakukan pola hidup sehat, termasuk melakukan latihan fisik atau berolahraga. ${ }^{6}$

Senam otak dan senam poco-poco merupakan latihan fisik yang dapat dilakukan oleh lansia untuk menjaga dan mempertahankan fungsi eksekutif mereka. Senam otak adalah serangkaian latihan gerakan tubuh dinamis dan sederhana yang bertujuan untuk mengoptimalkan aktivitas seluruh bagian otak dan meningkatkan fungsi kognitif. ${ }^{7-9}$ Senam otak ini dapat dilakukan oleh seluruh golongan usia, dari anak-anak hingga lansia, karena gerakangerakan dalam senam otak ini cukup mudah dan aman dilakukan. Senam Poco-poco adalah sebuah senam yang diadaptasi dari tarian khas, dari Sulawesi dengan unsur aerobik, kontinu, ritmikal, progresif, serta dapat merangsang fungsi eksekutif melalui retensi atensi visual dan auditorik, konsentrasi, serta melakukan gerakan yang tergolong mudah hingga kompleks. ${ }^{10-11}$ Senam Poco-poco sendiri jika dapat lebih memengaruhi dalam mempertahankan bahkan meningkatkan fungsi eksekutif lansia, seharusnya dapat diperkenalkan lebih lagi ke masyarakat luas dan dunia internasional sebagai salah satu upaya untuk memperkenalkan dan menjaga senam Poco-poco, yang merupakan salah satu budaya asli Indonesia.

Beberapa penelitian mengenai pengaruh intervensi senam otak dan senam Poco-poco terhadap fungsi kognitif lansia telah dilakukan secara terpisah. Penelitian intervensi yang dilakukan
Theresa dkk menyatakan terdapat pengaruh senam Poco-poco terhadap peningkatan fungsi eksekutif ibu rumah tangga, Sangundo dkk menyatakan terdapat pengaruh senam otak terhadap peningkatan fungsi kognitif lansia, dan Ersyanti dkk menyatakan terdapat pengaruh senam otak terhadap peningkatan fungsi kognitif lansia, terutama fungsi eksekutif. ${ }^{10,12-13}$ Berdasarkan hal-hal tersebut, tujuan penelitian ini untuk melihat perbedaan pengaruh senam otak dan senam poco-poco terhadap fungsi eksekutif lansia.

\section{METODE}

Penelitian inimenggunakan studi eksperimental dengan pendekatan quasi experimental pre and posttest. Penelitian ini berlangsung masing-masing selama empat minggu, yaitu bulan Juli-Agustus 2019 di (PUSAKA) 88, Kecamatan Tambora, Jakarta Barat dan bulan Agustus-September 2019 di PUSAKA 67, Kecamatan Cengkareng, Jakarta Barat. Subyekpenelitian merupakan lansia binaan PUSAKA 88 dan PUSAKA 67. Cara pengambilan sampel menggunakan purposive sampling berdasarkan kriteria inklusi dan eksklusi di masing-masing PUSAKA untuk melakukan pretest, intervensi, dan posttest. Kriteria inklusi dalam penelitian ini adalah lansia yang berusia di atas 60 tahun, tidak melakukan senam otak dan/atau senam poco-poco sebagai latihan fisik rutin, serta menyetujui informed consent penelitian. Kriteria eksklusi penelitian ini adalah lansia yang tidak kooperatif, mengalami gangguan penglihatan, pendengaran, dan/atau bicara sehingga sulit berkomunikasi, mengalami gangguan dalam hal membaca, menulis, dan/atau menggambar, mengalami disabilitas, serta gangguan mental. Kriteria drop out dalam penelitian ini adalah subyekyang tidak mengikuti serangkaian kegiatan penelitian secara lengkap selama kegiatan penelitian berlangsung dan tidak sepenuhnya mengikuti gerakan senam yang diinstruksikan oleh instruktur selama penelitian berlangsung (Gambar 1).

Subyek yang telah sesuai dengan kriteria inklusi dan eksklusi melakukan pretest berupa pertanyaan terkaitidentitas dankarakteristikdemografiresponden, pemeriksaan Montreal Cognitive Assessment versi Indonesia (MoCA-Ina), dan pemeriksaan Oral Trail 


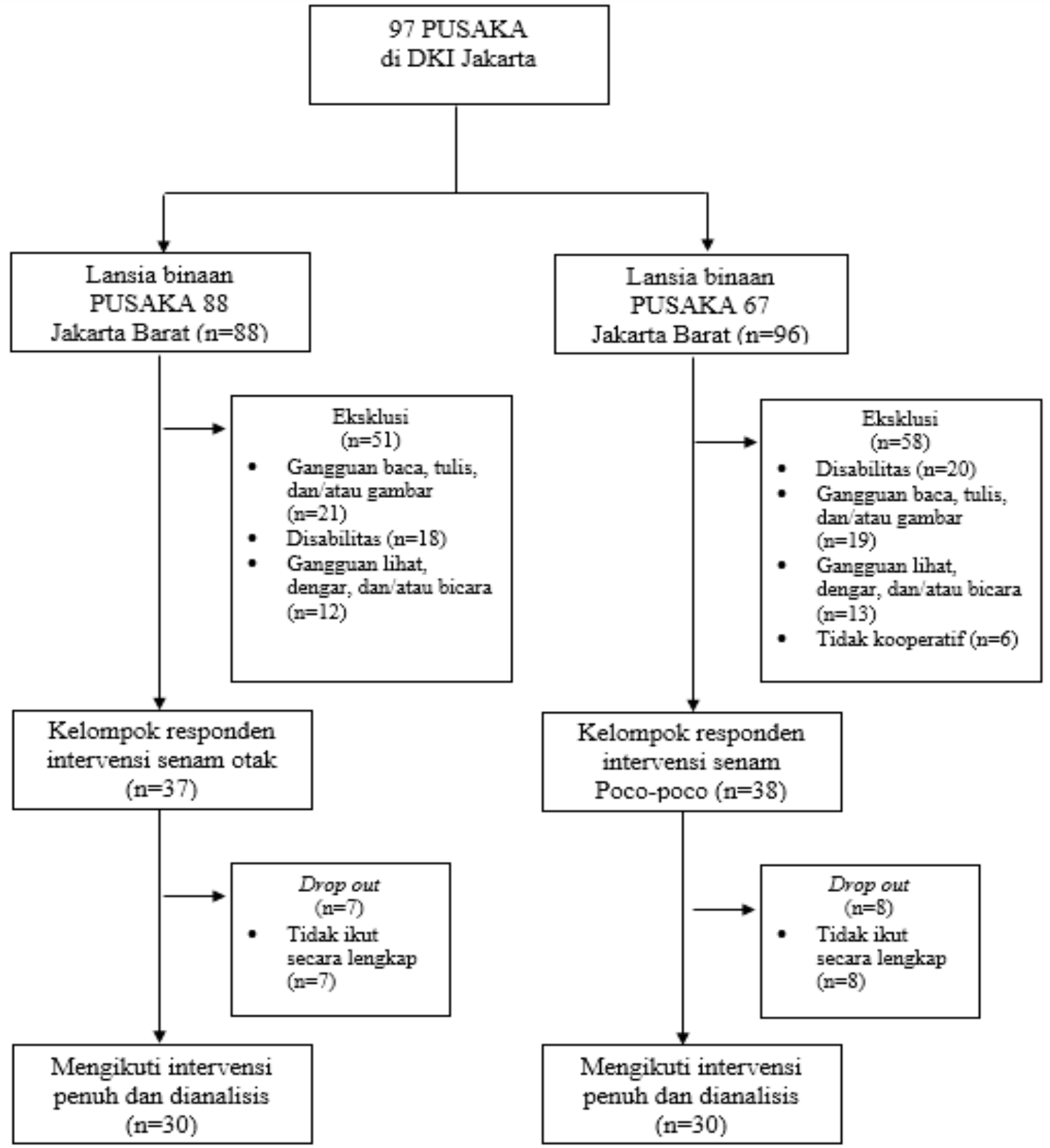

Gambar 1. Algoritma Responden

Making Test Form B (OTMT-B). Intervensi senam otak dilakukan oleh subyek di PUSAKA 88 dan senam Poco-poco dilakukan oleh subyek di PUSAKA 67, masing-masing sebanyak tiga kali seminggu selama tiga puluh menit dalam empat minggu. Pada intervensi senam otak, ada sebanyak delapan gerakan yang dilakukan secara berurutan oleh lansia, yaitu Cross Crawl, The Owl, Positive Point, The Thinking Cap, Balance Buttons, Earth Buttons, Space Buttons, dan Cook's Hook Up. Posttest berupa pemeriksaan OTMT-B dilakukan setelah masing-masing intervensi terakhir dilakukan oleh para responden.
Seluruh data penelitian diolah dan dianalisis pada program SPSS versi 23. Nilai kemaknaan yang digunakan dalam penelitian ini sebesar 0,05 . Uji analisis statistik yang digunakan dalam penelitian ini adalah uji Wilcoxon untuk melihat pengaruh masingmasing senam otak dan senam Poco-poco terhadap durasi penyelesaian OTMT-B. Uji analisis statistik yang digunakan dalam penelitian ini adalah uji Mann-Whitney untuk melihat perbedaan pengaruh senam otak dan senam poco-poco terhadap durasi penyelesaian OTMT-B. Penelitian ini telah disetujui oleh komite etik penelitian Fakultas Kedokteran dan 
Ilmu Kesehatan Universitas Katolik Indonesia Atma Jaya ( nomor persetujuan 03/07/KEP-FKUAJ/2019)

\section{HASIL}

Sebanyak total enam puluh orang menjadi subyek penelitian ini, yang terbagi ke kelompok intervensi senam otak sebanyak tiga puluh lansia binaan PUSAKA 88 dan kelompok intervensi senam poco-poco sebanyak tiga puluh lansia binaan PUSAKA 67. Karakteristik demografi Subyek dapat dilihat pada Tabel 1. otak dan senam Poco-poco sebelum dan sesudah masing-masing intervensi dilakukan. Pada kelompok senam otak, terdapat perbaikan durasi penyelesaian OTMT-B sebesar 23,49 detik atau 18,7\%. Pada kelompok senam Poco-poco terdapat perbaikan durasi penyelesaian OTMT-B sebesar 84,4 detik atau $54,3 \%$. (Tabel 3).

Uji normalitas data menggunakan uji ShapiroWilk menunjukkan distribusi data dalam penelitian ini tidak normal, sehingga uji analisis statistik

Tabel 1. Karakteristik Demografi Subyek Penelitian $(n=60)$

\begin{tabular}{|c|c|c|c|c|}
\hline Karakteristik & $\begin{array}{l}\text { Senam Otak } \\
\quad(n=30)\end{array}$ & Keterangan & $\begin{array}{c}\text { Senam Poco-poco } \\
(\mathbf{n}=\mathbf{3 0})\end{array}$ & Keterangan \\
\hline \multicolumn{5}{|l|}{ Usia } \\
\hline - 60-69 tahun, $\mathrm{n}(\%)$ & $21(30)$ & Min: 61 & $23(76,7)$ & Min: 60 \\
\hline - $70-79$ tahun, $\mathrm{n}(\%)$ & $7(23,3)$ & Maks: 86 & $7(23,3)$ & Maks: 78 \\
\hline - $\quad$ 80-89 tahun, $\mathrm{n}(\%)$ & $2(6.7)$ & & $0(0)$ & \\
\hline \multicolumn{5}{|l|}{ Jenis Kelamin } \\
\hline - Laki-laki, n (\%) & $6(20)$ & & $1(3,3)$ & \\
\hline - Perempuan, n (\%) & $24(80)$ & & $29(96,7)$ & \\
\hline \multicolumn{5}{|l|}{ Tingkat Pendidikan Terakhir } \\
\hline - Tidak sekolah & $6(20)$ & & $14(46,7)$ & \\
\hline - Tamat SD & $19(63,3)$ & & $14(46,7)$ & \\
\hline - Tamat SMP & $5(16,7)$ & & $1(3,3)$ & \\
\hline - Tamat SMA & $0(0)$ & & $1(3,3)$ & \\
\hline \multicolumn{5}{|l|}{ Riwayat Penyakit Kronis } \\
\hline - Ada, n (\%) & $21(70)$ & & $25(83,3)$ & \\
\hline ○ Penyakit kardiovaskuler & 14 & & 12 & \\
\hline$\circ$ Penyakit metabolik & 5 & & 9 & \\
\hline$\circ$ Penyakit urogenital & 0 & & 1 & \\
\hline ○ Penyakit digestif & 6 & & 9 & \\
\hline o Penyakit respirasi & 0 & & 3 & \\
\hline ○ Penyakit muskuloskeletal & 10 & & 6 & \\
\hline$\circ$ Penyakit neurologi & 1 & & 1 & \\
\hline - Penyakit terkait sistem indera & 0 & & 2 & \\
\hline$\circ$ Penyakit keganasan & 0 & & 0 & \\
\hline - $\quad$ Tidak ada, n $(\%)$ & $9(30)$ & & $5(16,7)$ & \\
\hline
\end{tabular}

Min: minimal; Maks: maksimal.

Durasi penyelesaian OTMT-B pada kelompok intervensi senam otak dan senam Poco-poco, baik sebelum dan sesudah pemberian masing-masing intervensi dapat dilihat pada Tabel 2. Hasil analisis statistik menunjukkan bahwa terdapat perbaikan durasi penyelesaian OTMT-B pada kelompok senam menggunakan uji Wilcoxon dan uji Mann-Whitney. Nilai p pada kelompok intervensi senam otak sebesar 0,021 menunjukkan adanya pengaruh senam otak terhadap fungsi eksekutif lansia di PUSAKA 88. Nilai p pada kelompok intervensi senam pocopoco sebesar 0,000 menunjukkan adanya pengaruh 
Tabel 2. Gambaran status fungsi kognitif subyek berdasarkan pemeriksaaan MoCA-Ina $(n=60)$

\begin{tabular}{lcc}
\hline $\begin{array}{l}\text { Status Fungsi } \\
\text { Kognitif }\end{array}$ & $\begin{array}{c}\text { Senam Otak } \\
(\mathbf{n = 3 0 )}\end{array}$ & $\begin{array}{c}\text { Senam Poco-poco } \\
(\mathbf{n = 3 0})\end{array}$ \\
\hline $\begin{array}{l}\text { Normal, n (\%) } \\
\text { Gangguan Fungsi }\end{array}$ & $2(6,7)$ & $2(6,7)$ \\
Kognitif, n (\%) & $28(93,3 \%)$ & $28(93,3 \%)$ \\
\hline
\end{tabular}

senam poco-poco terhadap fungsi eksekutif lansia di PUSAKA 67. Nilai $\mathrm{p}$ pada perbedaan rata-rata perubahan durasi penyelesaian OTMT-B kelompok intervensi senam otak dan senam poco-poco sebesar 0,006 menunjukkan terdapat perbedaan peningkatan fungsi eksekutif setelah intervensi senam otak dan senam Poco-poco dilakukan. Peningkatan fungsi eksekutif ditemukan lebih signifikan pada kelompok senam Poco-poco dibandingkan senam otak. (Tabel 4).

Beberapa subyek yang sebenarnya telah sesuai dengan kriteria inklusi dan tidak terdapat kriteria eksklusi tidak mengikuti intervensi senam otak atau senam Poco-poco secara lengkap sampai intervensi terakhir dilakukan sehingga termasuk ke dalam kriteria drop out. Beberapa alasan berdasarkan observasi dan wawancara yang dilakukan peneliti terhadap pengurus masing-masing PUSAKA adalah beberapa subyek kelompok senam otak merupakan lansia yang mudah mengalami penurunan kondisi fisik dan ada yang berhalangan dengan beberapa alasan tertentu sehingga saat intervensi dilakukan mereka tidak dapat hadir dan mengikutinya.
Sementara beberapa subyek kelompok senam Poco-poco memiliki tempat tinggal yang cukup jauh dari tempat dilakukannya intervensi sehingga mereka memutuskan untuk pulang lebih dahulu dan ada yang merasa malas untuk mengikuti intervensi karena mereka lebih memilih untuk melakukan halhal lain setelah melakukan aktivitas di PUSAKA dibandingkan melakukan senam Poco-poco. Subyek lainnya yang melakukan senam otak atau senam Poco-poco secara lengkap sampai intervensi berakhir merasa sangat senang, lebih rileks dan tenang, serta tubuh lebih segar dan bugar dibandingkan sebelum mengikuti intervensi di masing-masing kelompok, terutama senam Poco-poco.

\section{PEMBAHASAN}

Lansia yang mengalami gangguan fungsi kognitif, termasuk fungsi eksekutif, dipengaruhi berbagai faktor dengan berbagai mekanisme, seperti usia yang terus bertambah, jenis kelamin perempuan, lama pendidikan yang lebih singkat, dan mempunyai riwayat penyakit kronis. Hal-hal tersebut juga ditemukan pada Subyek yang mengalami gangguan fungsi kognitif, termasuk fungsi eksekutif dalam penelitian ini. ${ }^{5}$ Pada kelompok Subyek yang melakukan intervensi senam otak, terdapat perbaikan durasi penyelesaian OTMT-B yang menunjukkan peningkatan fungsi eksekutif. Hal ini sesuai dengan tujuan senam otak, yaitu untuk meningkatkan fungsi kognitif dengan cara merangsang dan merelaksasi

Tabel 3. Rerata, Standar Deviasi, dan Selisih Rerata Durasi Penyelesaian Oral Trail Making Test Form B (OTMT-B) sebelum dan sesudah Intervensi pada Kelompok Senam Otak dan Senam Poco-poco (n=60)

\begin{tabular}{|c|c|c|c|c|c|c|c|c|c|c|}
\hline \multirow[b]{2}{*}{ Variabel } & \multicolumn{5}{|c|}{ Senam Otak $(n=30)$} & \multicolumn{5}{|c|}{ Senam Poco-poco $(n=30)$} \\
\hline & Pretest & Posttest & $\begin{array}{c}\text { Selisih } \\
(\%)\end{array}$ & $\mathbf{p}^{*}$ & Z-Score & Pretest & Posttest & $\begin{array}{c}\text { Selisih } \\
(\%)\end{array}$ & $p^{*}$ & Z-Score \\
\hline $\begin{array}{c}\text { Rata-rata (detik) } \pm \\
\text { standar deviasi }\end{array}$ & $\begin{array}{c}125,58 \pm \\
110,77\end{array}$ & $\begin{array}{c}102,08 \pm \\
103,69\end{array}$ & $\begin{array}{l}-23,49 \\
(18,71)\end{array}$ & 0,021 & $-2,301$ & $\begin{array}{c}155,35 \pm \\
122,27\end{array}$ & $\begin{array}{c}70,96 \pm \\
69,59\end{array}$ & $\begin{array}{c}-84,4 \\
(54,33)\end{array}$ & 0,000 & $-4,167$ \\
\hline
\end{tabular}

* Uji Wilcoxon

Tabel 4. Perbedaan Selisih Rerata Durasi Penyelesaian Oral Trail Making Test Form B (OTMT-B) Sesudah Intervensi pada Kelompok Senam Otak dan Senam Poco-poco $(n=60)$

\section{Durasi Penyelesaian}

Oral Trail Making Test Form B (Selisih Rata-rata)

\begin{tabular}{ccccc}
\hline Variabel & Senam otak & Senam Poco-poco & p* & $Z$ Z-Score \\
\hline \multirow{2}{*}{ Rata-rata (detik) \pm standar deviasi } & $-23,49 \pm$ & $-84,4 \pm$ & 0,006 & $-2,767$ \\
\hline
\end{tabular}

*Uji Mann-Whitney 
bagian otak, serta meningkatkan koordinasi organ indera dengan otak. $^{7-9}$ Delapan gerakan senam otak yang dilakukan secara benar dan teratur dapat merangsang dimensi lateralis, pemfokusan, dan pemusatan, untuk lebih meningkatkan kerja otak dan fungsi kognitif, termasuk fungsi eksekutif, serta melancarkan aliran darah dan pasokan oksigen ke jaringan otak. ${ }^{7}$ Penelitian lain yang sesuai dengan penelitian ini, yaitu yang dilakukan oleh Ersyanti dkk menyatakan bahwa setelah dilakukan intervensi senam otak sebanyak dua kali seminggu selama delapan minggu dan penelitian oleh Wariyanti dkk menyatakan intervensi senam otak yang dilakukan tiga kali seminggu selama empat minggu dapat meningkatkan fungsi kognitif lansia, termasuk fungsi eksekutif. ${ }^{13-14}$

Pada kelompok subyek yang melakukan intervensi senam Poco-poco, terdapat perbaikan durasi penyelesaian OTMT-B yang menunjukkan peningkatan fungsi eksekutif. Senam Poco-poco dapat memengaruhi dan merangsang fungsi eksekutif melalui retensi atensi dan memori dalam mengingat setiap detail gerakan senam, konsentrasi dalam memutuskan, menyesuaikan gerakan dengan irama dan ketukan lagu Poco-poco yang diputar, serta koordinasi melakukan gerakan yang agak kompleks dan asosiasi antargerakan dengan tingkat kesulitan sedang dalam suasana yang menyenangkan. ${ }^{10}$ Intervensi senam Poco-poco yang dilakukan secara benar dan teratur dapat menyebabkan perubahan plastisitas sinaps, neurogenesis, dan angiogenesis di tingkat biomolekuler dan seluler, serta peningkatan brain-derived neurotrophic factor (BDNF) yang berperan dalam neuroplastisitas dan neuroprotektif hingga menyebabkan perangsangan dan peningkatan aktivitas neuronal di korteks prefrontalis pada tingkat sistemik sehingga terjadi peningkatan fungsi eksekutif setelah intervensi senam Poco-poco dilakukan. ${ }^{10}$

Pada selisih rerata durasi penyelesaian OTMT-B sesudah intervensi senam otak dan senam Poco-poco, terdapat perbedaan pengaruh senam otak dan senam Poco-poco yang bermakna secara statistik, walaupun kedua senam tersebut sama-sama memengaruhi fungsi eksekutif lansia. Senam Poco-poco lebih berpengaruh positif terhadap fungsi eksekutif lansia dibandingkan senam otak, baik secara klinis (perbaikan durasi penyelesaian OTMT-B yang lebih tinggi pada kelompok senam Poco-poco dibandingkan kelompok senam otak) dan uji statistik. Senam otak dan senam Poco-poco memiliki perbedaan dalam gerakan dan tujuan dari masing-masing senam tersebut. Delapan gerakan senam otak dengan gerakan ekstremitas bagian atas yang lebih banyak dilakukan oleh kelompok subyek intervensi senam otak dapat lebih meningkatkan kemampuan untuk merangsang, memaksimalkan fungsi otak, dan koordinasi dengan organ indera dan ekstremitas tubuh lainnya secara langsung terkait dengan fungsi kognitif, termasuk bagian korteks prefrontalis yang mengatur fungsi eksekutif. ${ }^{7,9}$ Dimensi lateralis, pemfokusan, dan pemusatan dapat bekerja lebih baik dan optimal karena langsung dirangsang oleh gerakan-gerakan senam otak, termasuk pengaturan kerja fungsi eksekutif yang dirangsang dimensi pemfokusan. ${ }^{9}$

Gerakan senam Poco-poco yang bersifat aerobik, kontinu, ritmikal, dan progresif memiliki banyak pengaruh terhadap tubuh manusia, seperti menurunkan profil lipid dan gula darah, meningkatkan daya kerja jantung, menurunkan berat badan dan tekanan darah, serta meningkatkan tingkat $\mathrm{VO}_{2}$ maksimum. ${ }^{11,15}$ Karena kebutuhan oksigenasi jaringan otak meningkat saat melakukan latihan fisik, aliran darah ke otak meningkat untuk meningkatkan perfusi dan oksigenasi ke jaringan otak, sehingga fungsi kognitif dapat meningkat. ${ }^{16}$ Delapan kelompok gerakan dan dua gerakan transisi senam Pocopoco dengan banyak gerakan ekstremitas bagian atas dan bawah dan tergolong gerakan low aerobic yang dilakukan oleh kelompok subyekintervensi senam Poco-poco dapat memengaruhi struktural dan fungsional organ tubuh manusia, termasuk korteks prefrontalis yang mengatur fungsi eksekutif. ${ }^{10}$

Hal - hal lain yang membedakan senam otak dan senam Poco-poco adalah dari segi pelaksanaannya. Setiap orang yang melakukan senam otak tidak perlu mempersiapkan banyak hal karena senam otak tergolong praktis untuk dilakukan di mana saja, kapan saja, dan oleh siapa saja, termasuk lansia, sehingga mudah untuk melakukan senam otak. Pada senam Poco-poco, gerakan berulang mengikuti putaran jarum 
Tabel 5. Jumlah Subyek Kelompok Senam Otak dan Senam Poco-poco Berdasarkan Karakteristik Demografi yang Mengalami Perbedaan Selisih Rerata Durasi Penyelesaian Oral Trail Making Test Form B (OTMT-B) sesudah Intervensi $(n=60)$

\begin{tabular}{|c|c|c|c|c|}
\hline \multirow[b]{2}{*}{ Karakteristik Demografi } & \multicolumn{2}{|c|}{ Senam Otak } & \multicolumn{2}{|c|}{ Senam Poco-poco } \\
\hline & $\begin{array}{c}\text { Perbaikan } \\
\text { Durasi OTMT-B }\end{array}$ & $\begin{array}{c}\text { Tetap dan/atau } \\
\text { Perburukan Durasi } \\
\text { OTMT-B }\end{array}$ & $\begin{array}{c}\text { Perbaikan Durasi } \\
\text { OTMT-B }\end{array}$ & $\begin{array}{c}\text { Tetap dan/atau } \\
\text { Perburukan Durasi } \\
\text { OTMT-B }\end{array}$ \\
\hline \multicolumn{5}{|l|}{ Usia } \\
\hline - 60-69 tahun & 10 & 11 & 18 & 5 \\
\hline - 70-79 tahun & 5 & 2 & 6 & 1 \\
\hline - $80-89$ tahun & 1 & 1 & 0 & 0 \\
\hline \multicolumn{5}{|l|}{ Jenis Kelamin } \\
\hline - Laki-laki & 3 & 3 & 1 & 0 \\
\hline - Perempuan & 13 & 11 & 23 & 6 \\
\hline \multicolumn{5}{|l|}{ Tingkat Pendidikan Terakhir } \\
\hline - Tidak sekolah & 4 & 10 & 10 & 4 \\
\hline - Tamat SD & 9 & 2 & 12 & 2 \\
\hline - Tamat SMP & 3 & 2 & 1 & 0 \\
\hline - Tamat SMA & 0 & 0 & 1 & 0 \\
\hline \multicolumn{5}{|l|}{ Riwayat Penyakit Kronis } \\
\hline - Ada & 11 & 10 & 20 & 5 \\
\hline - Tidak ada & 5 & 4 & 4 & 1 \\
\hline \multicolumn{5}{|l|}{ Nilai MoCA-Ina } \\
\hline - Normal & 2 & 2 & 2 & 0 \\
\hline - Gangguan Fungsi Kognitif & 14 & 0 & 22 & 6 \\
\hline
\end{tabular}

OTMT-B: Oral Trail Making Test Form B; MoCA-Ina: Montreal Cognitive Assessment versi bahasa Indonesia.

jam menyebabkan orang yang sedang melakukan senam Poco-poco membutuhkan area yang cukup luas dan lapang, terutama jika jumlah orang yang melakukan senam Poco-poco cukup banyak. Selain itu, senam Poco-poco juga lebih membutuhkan pengeluaran energi yang lebih besar dibandingkan dengan senam otak karena beberapa gerakan ada yang cukup cepat dan menyebabkan banyak otot mengalami kontraksi dan terjadi penumpukan asam laktat, sehingga beberapa subyekkelompok senam Poco-poco merasa sedikit kelelahan setelah melakukan senam Poco-poco.

Pada analisis lanjutan selisih rerata durasi penyelesaian OTMT-B pada kelompok senam otak dan senam Poco-poco berdasarkan karakteristik demografi Subyekmasing-masing kelompok secara kualitatif, terdapat perbaikan durasi penyelesaian OTMT-B yang menunjukkan adanya pengaruh positif senam otak dan senam Poco-poco terhadap fungsi eksekutif (Tabel 5). Pada kelompok senam otak, perbaikan durasi OTMT-B lebih banyak terjadi pada subyek dengan rentang usia 80-89 tahun, lakilaki, tamat SMP, tidak memiliki riwayat penyakit kronis, serta mengalami gangguan fungsi kognitif. Sementara pada kelompok senam Poco-poco, perbaikan durasi OTMT-B lebih banyak terjadi pada Subyek dengan rentang usia 60-69 dan 70-79 tahun, perempuan, tidak sekolah dan tamat SD, mempunyai riwayat penyakit kronis, serta mengalami gangguan fungsi kognitif. Sehingga dapat disarankan bagi lansia dengan beberapa karakteristik demografi tersebut melakukan senam otak atau senam Pocopoco yang sesuai dengan hasil perubahan durasi penyelesaian OTMT-B untuk mempertahankan bahkan meningkatkan fungsi eksekutif.

Pada penelitian yang dilakukan oleh Cancela $\mathrm{dkk}^{17}$ tidak ditemukan perbedaan pengaruh signifikan 
terhadap fungsi kognitif lansia, termasuk fungsi eksekutif, yang melakukan senam otak dan latihan fisik tradisional Spanyol. Hal tersebut mungkin dapat terjadi karena durasi waktu kombinasi latihan fisik tradisional Spanyol dan senam otak yang lebih lama dari tiga puluh menit dan sifat gerakan dalam latihan fisik tradisional Spanyol tidak seluruhnya bersifat aerobik sehingga tidak terdapat pengaruh latihan fisik tradisional Spanyol terhadap fungsi kognitif. Durasi latihan fisik yang tepat bagi lansia untuk meningkatkan fungsi kognitifnya, termasuk fungsi eksekutif, sekitar 20-30 menit. Berdasarkan penelitian dan data di atas, senam otak dan senam Poco-poco mempunyai pengaruh positif terhadap fungsi eksekutif lansia melalui berbagai mekanisme.

Kekuatan penelitian ini adalah tidak terdapat self-selection bias karena peneliti telah menentukan tempat pelaksanaan penelitian di dua tempat yang berbeda, sehingga Subyek hanya melakukan intervensi yang telah ditetapkan lebih peneliti dan kegiatan monitoring, serta evaluasi dilakukan secara mandiri oleh peneliti sesuai dengan prosedur. Keterbatasan penelitian ini adalah adanya faktor-faktor lain yang dapat memengaruhi penurunan fungsi eksekutif lansia sebagai faktor perancu penelitian dan tidak diperhitungkan, seperti usia lansia yang terlalu tua, tingkat pendidikan rendah, nilai fungsi kognitif rendah, adanya riwayat penyakit kronis, serta tidak memperhitungkan faktor-faktor yang dapat memengaruhi penurunan fungsi eksekutif lansia, seperti rutinitas latihan fisik yang dilakukan, status gizi, dan gangguan psikis (depresi dan ansietas).

\section{KESIMPULAN}

Terdapat perbedaan peningkatan fungsi eksekutif lansia setelah dilakukannya intervensi senam otak dan senam Poco-poco pada lansia. Senam Pocopoco lebih meningkatkan fungsi eksekutif lansia dibandingkan senam otak. Hasil dari penelitian ini diharapkan menjadi salah satu sumber ilmu yang menyatakan latihan fisik senam otak maupun senam Poco-poco sebaiknya dilakukan secara rutin sebagai program dalam rencana kegiatan atau aktivitas rutin komunitas lansia untuk mempertahankan bahkan meningkatkan fungsi eksekutif lansia.

\section{DAFTAR PUSTAKA}

1. Badan Pusat Statistik. Statistik penduduk lanjut usia 2017; 2017.

2. United Nations. World population ageing 2017; 2017.

3. Morley JE. The new geriatric giants. Clin Geriatr Med [serial online]. 2017 [diunduh 13 November 2018];33(3):xi-xii. Tersedia dari: Clinic and Geriatric Medicine.

4. Kelly DP, Natale MJ. Neurodevelopmental function and dysfunction in the school-age child. Dalam: Kliegman RM, Santon B, Geme J, Schor NF. Nelson Textbook of Pediatrics. Edisi ke-20. Philadelphia, PA: Elsevier; 2016. h. 192-9.

5. Diamond A. Executive functions. Annu Rev Psychol. 2013;64:135-68.

6. Theresa RM. Hubungan antara fungsi kognitif dengan tingkat kemandirian dan kualitas hidup warga usia lanjut. Bina Widya UPN Veteran Jakarta. 2013;24(3):139-44.

7. Dennison PE, Dennison GE. Brain gym (senam otak): gerakan sederhana untuk belajar dengan keseluruhan otak. Jakarta: Grasindo; 2002. h.19-30.

8. Desiningrum DR, Indriana Y. Modul pelatihan senam otak untuk adiyuswa. Edisi pertama. Semarang: Fastindo; 2018. h. 5-6.

9. Sularyo TS, Handryastuti S. Senam otak. Sari Pediatri. 2016;4(1):36-44.

11. Wulandari N, Suratih K, Sari DK. Pengaruh gerak ritmik senam poco-poco terhadap kadar gula darah (blood sugar) pada penderita diabetes melitus di Dusun Guwosari Jebres Surakarta [skripsi]. STIKES 'Aisyiyah Surakarta; 2017.

12. Sangundo MF, Sagiran. Pengaruh brain gym terhadap fungsi kognitif pada usia lanjut. Mutiara Med J Kedokt Dan Kesehat. 2016;9(2):86-94.

13. Ersyanti EA, Setyopranoto I, Setyaningrum CTS. Pengaruh senam otak terhadap perbaikan kognitif lansia di pakem Yogyakarta [tesis]. Universitas Gadjah Mada; 2018.

14. Wariyanti A, Sugiyanto EP, Kandar. Perbedaan terapi brain gym dan vitalisasi otak terhadap kemampuan fungsi kognitif lansia di panti werda elim semarang. Karya Ilm. 2017;6(1):349-61.

15. Sari YK. Upaya penurunan tekanan darah pada lansia melalui senam poco-poco nusantara versi kesehatan sekecamatan Weru Kabupaten Sukoharjo. Ilm SPIRIT. 2017;16(2):60-72.

16. Lucas-Cuevas ÁG, Quesada JIP, Pérez-Soriano $\mathrm{P}$, Llana-Belloch S. Effects of the exercise in the cerebral blood flow and metabolism: a review. J Hum Sport Exerc. 2015;10(1):150-60. 
17. Cancela JM, Vila Suárez MH, Vasconcelos J, Lima A, Ayán C. Efficacy of brain gym training on the cognitive performance and fitness level of active older adults: a preliminary study. J Aging Phys Act. 2015;23(4):653-8. 